\title{
Experiential Outdoor Activities In Improving Students' Vocabulary Achievement
}

\author{
Musrafidin Simanullang ${ }^{1}$ \\ ${ }^{1}$ Universitas Sisingamangaraja XII Tapanuli
}

\begin{abstract}
This research is A Classroom Action Research held at SMP Negeri 4 Sipoholon in Academic Year 2018/2019. The problem of the research is; Does experiential outdoor activities significantly improve the students' vocabulary achievement of the eight grade students at SMP Negeri 4 Sipoholon? And the objective is to find out whether experiential outdoor activities significantly improve the students' vocabulary achievement. The subject of the research is 20 students of the eight grade students of SMP N. 4 Sipoholon in academic year 2018/2019. In pre-test there was no student who got good and very good interpretation yet there are one who was fail and 8 students who were poor, in the minimum criterion used in the school is 70, while based on the data analysis of the post-test that there are 11 students who got very good (80-100) and 9 students got good (66-79), and none of the students got fair (56-65), poor (40$55)$, and fail (<39). It means all the students passed the minimum criterion applied in that school.
\end{abstract}

Keywords: Experiential Outdoor Activities, Students' Vocabulary Achievement

\section{INTRODUCTION}

English Language Learners (ELL) often feel that vocabulary is their most frequent obstacle when having to access information from classroom texts (Silverman \& Hines, 2009). This can be problematic knowing how vocabulary acquisition is a critical component of academic language. Therefore, ELL students are having to learn both the English language and the academic language at the same time. Although many students can learn new vocabulary through incidental learning while listening to a read aloud, ELL students have a much harder time with this because so many words are unknown to them. Therefore, ELL students need to have direct instruction with vocabulary words.

Language as a tool of communication plays an important roles in society. People use language to communicate among people whether in their society or in this world. Every social instruction in this world is using languages to communicate each other: law, religion, education, and family all of them interacted by using language, and the language which is frequently used in international communication is English language.

There are many students with learning difference; problems and disabilities have weak language skills that directly impact their vocabulary development. Most individuals who can read and have least vocabulary in a school education would consider their vocabulary adequate. Adequate 
meaning that the person can understand oral communication, express one's thoughts in speech and is able to comprehend common reading material. But many individual with learning differences have weak vocabularies. Mastering vocabulary can help to get easier to use a language, large vocabulary can help to express ideas precisely in communication. Vocabulary knowledge enables language use; language enables the increased of it, and knowledge of the world enables the increase of it and language use and so on. Naturally, learning vocabulary is complex. It is because a lot of cases where the learners have to understand certain elements, such as, spelling, word classes, such as, noun, verb, adverb, adjective, conjunction, article, etc.

It is indeed very necessary to help our learners to acquire sufficient vocabulary for communication in the second language. The use of creative methods in teaching vocabulary can improve students' word knowledge and continue to acquire more words outside classroom. Vocabulary is important elements of language knowledge because they appear in speaking, listening, reading and writing. Beginners often manage to communicate in English by using the accumulative effect of individual words. Without a proportional amount of vocabulary, anyone will get trouble in their language skills. It means that vocabulary is the main point of the students in beginning of process in English language learning.

In Indonesia, certainly, English language has affects many aspects in Indonesia especially in education. However, students entering college or school are expected to know enough word knowledge and proficiency in English to overcome with the demands arising from having to handle it. Sometimes, it is because the learner needs to go to another state or to other parts of the country for educational or occupational purposes. A student is usually required to take an examination, for entry into a specialist field of study or a job or face interviews that use English language. In such cases, the learner has to master English words to communicate and overcome the demands of the present day society.

As a result, the writer is interested to conduct a research entitled "Experiential Outdoor Activities in Improving Students' Vocabulary Achievement of the Eight Grade Students at SMP Negeri 4 Sipoholon in Academic Year 2018/2019"

In relation to the background of the study, the research problem of this study is formulated as follows: Does experiential outdoor activities significantly improve the students' vocabulary achievement of the eight grade students at SMP Negeri 4 Sipoholon?

Referring to the research problem of the study, the objective of this study is to find out whether experiential outdoor activities significantly improve the students' vocabulary achievement. 
This research was conducted only to one class of the the eight grade students at SMP Negeri 4 Sipoholon in academic year 2018/2019. The research deals with and focus on the students' vocabulary achievement by experiential outdoor activities.

The result of this research expected to give significant effects not only theoretical but also practical:

- Students: it is expected to make process of learning more enjoyable and communicative so that it will increase not only their motivation and interest but also their vocabularies in learning English. The researcher hopes that this research will give significant advantages in reinforcing vocabulary on students.

- Teacher: it is expected to able to enrich the teachers' knowledge in term of the teaching English by experiential outdoor activities.

- Other researcher: it is expected that the result of this study will be useful as a basic consideration and basic information to do further investigation or research.

- In terms of bringing clarity to the research problem, the researcher formulates the research hypothesis as follows:

- Null Hypothesis (Ho): There is no significant improvement of students' vocabulary achievement taught by experiential outdoor activities.

- Alternative Hypothesis (Ha): There is significant improvement of students' vocabulary achievement taught by experiential outdoor activities.

There are several definition stated by some expert about vocabulary. Hornby (1995: 959) states that vocabulary is the total number of words which make a language. It means vocabulary is the key to understand foreign language. Enrich oneself use vocabulary, someone can express ideas in communication easier. In line with Burn, (1999) states that vocabulary means 1) all the words means in particular language, 2) all the words that the person knows or uses, 3) a list of words with their meanings, especially in a book for learning a foreign language. From the definitions, it can be said that vocabulary is total number of words or stock of words with their meaning which make up a language used by person, class, or profession.

Vocabulary plays necessary role in learning a language so that it can help language learners to be able to understand and use language, especially a foreign language as according to Ur (1998: 60) vocabulary can be defined, roughly, as the words people teach in the foreign language. It means vocabulary is written or spoken unit of language as symbol of idea in foreign language introduced to learners. If a teacher teaches new words in foreign language, it means the teacher teaches 
vocabulary. According to Ur (1996: 60-62), there are some aspects of vocabulary that should be mastered by students as follows:

The students have to know what a word sounds like (its pronunciation) and what it looks like (its spelling). The grammatical rules should be understood by student when they learn a set of new words. The meaning of words is primarily what is refers to in the real world, its denotation. A less obvious component of the meaning of an item it is connotation: the association, or positive or negative feeling it evokes, which may not be indicated in a dictionary definition. A more subtle aspect of meaning that often needs to be taught is whether particular item is the appropriate one to use in a certain context or not. Hacth (1995) states that there are five essential steps in vocabulary learning. The first essential step for vocabulary learning is encountering new word form various sources. Encountering words are more effective when the students work with interactive and interesting material. The number of times that a word is encountered also affect whether its learned.

The important of getting the word form appears when students are asked to give definitions for words. Beginning students are likely to make mistakes that are related to confusions of the form of other words.

The specificity of the meaning that students need seems to vary. The level of distinction that must be made in word definition seems commit vary both with he requirement of the task or situation, and aslo with the level of students. One vary populer way in incidental learning for students to get the meaning of words is through context.

Interesting vocabulary learning can strengthen the form meaning connection. There are four strategies: (1) creating mental linkages, (2) applying images and sound, (3) reviewing well, (4) employing actions.

The final step in learning word is using the words. Usages provides a mild guarantee that word and meanings will not fade from memory once they are learned. That the researcher gave the student solution as follow; make the meaning of the word, and translating the word.

Vocabulary can be classified into some categories or kinds. Sheperd (1980: 1) divides vocabulary into two kinds, namely receptive vocabulary and expressive vocabulary (productive vocabulary). He defines receptive vocabulary as "the word known when the learner listens or reads". Receptive vocabulary is also considered as passive process since the learner only receives thought from others. In language application, the receptive vocabulary is regarded as the basic vocabulary. Later, expressive vocabulary is defined as "the word used when the learner speaks and writes". Therefore, the expressive vocabulary can be addressed 
as an active process because the learner produces or expresses thought to others. Generally, receptive vocabulary is much larger than expressive vocabulary because there are many word recognized when the learner hears or reads but do not use when he speaks or writes.

Vocabulary can also be classified into general vocabulary and specialized vocabulary. General vocabulary consists of words that are applied in various activities daily life. Specialized vocabulary arises from particular circumtstances of life and work such as doctor, pilot, enginer, and so on that must be specialized in order to be able to run their jobs or duties appropriately. Finaly, Tarigan (1988) categorizes the basic vocabulary which commonly used into seven types as follows:

a. Kindship, for example: child, son, father, uncle, nephew, etc.

b. Part of body, for example: hand, eye, head, leg, nose, etc.

c. Pronoun, for example: I, she, he, it, they, we, etc

d. Numerical, for example: one, two, three, sixteen, fourty, one hundred, etc.

e. Verbs, for example: eat, play, go, sit, walk, etc.

f. Adjectives, for example: beautiful, good, clever, bad, clean, etc.

g. Universal matter, for example: table, chair, bed, picture, door, etc.

The expressive vocabulary can be addressed as an active process because the learner produces or expresses thought to others. Generally, receptive vocabulary is much larger than expressive vocabulary because there are many word recognized when the learner hears or reads but do not use when he speaks or writes.

Experiential learning is generally concerned with learning that depends on first-hand experiences which connect the learner with real people and real issues. It is often associated with informal education although this is not exclusively so. Furthermore, it is generally considered to be a lifelong process integrating education, work and leisure.

Experiential learning is based on the premise that the learner learns best by doing and one of the teaching methods often employed is based on problem solving approaches. In this way experience becomes the catalyst for learning in other key government policy objectives such as citizenship and personal and social education. This means that experiential learning has direct relevance to the in helping the transition from secondary school to adult life and enhancing a range of 'personal and social skills' among young people.

It can be helpful to refer to models when thinking of these issues and two of the most frequently used are outlined on the figures below.

105 | Experiential Outdoor Activities In Improving Students' ..., Musrafidin Simanullang Jurnal Christian Humanioran | http://e-journal.iakntarutung.ac.id/index.php/humaniora 
Figure 2.1

\section{Kolb Cycle of Experiential Learning}

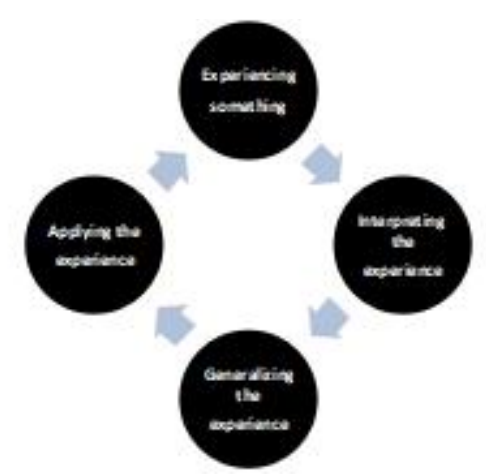

Kolb's cycle can be used to explain experiential ways of learning. The model does not really do justice to the complexity of the brain and its ability to process complicated information. It also implies that experience and reflection occur independent of each other, which is challengeable. It does however, provide a framework for thinking about the linkages between different components of learning processes.

Consequently, it offers a tool to think about how we work with young people. Take the initial experience component of the model. The suggestion here is that it is not sufficient for young people to take part in outdoor activities and for the teacher to assume that the experience will automatically translate into a learning outcome. The model implies that the experience does not speak for itself and that learning will not automatically occur as a result of participating in activities. Consequently young people are likely to need help with interpreting the experience. This is the role of the instructor/ teacher and can be effectively achieved through reviewing the outdoor activity in relation to the educational outcome in mind. The young person is also likely to need help in generalising the experience which involves making sense of the experience in relation to the learner's own social world (which is often not related to that where the experience has taken place). Having internalised this experience the model suggests that the learning cycle is not complete until the new learning has been applied. This means that the learner can apply their new thinking in a way that allows more informed decision making than had they not had the new experience.

Using this model helps to distinguish between the quality of experience because not all experiences are genuinely educative. Take for example the case of a person stealing cars for the purpose of joyriding. It is quite possible that the joy rider experiences enhanced levels of self-esteem through this activity. What is missing from this process is for the learner to be able to distinguish between something educative and something mis-educative (Dewey, 1963). There is a clear role for the instructor/teacher here where the purpose is to provide a structure to help young people learn from their experiences in a way that learning is not left to chance. In this manner we can distinguish 
between experiential training which is suited to the idea of skill acquisition inherent in activities, and experiential learning where activities are used in an instrumental manner to promote personal and social qualities. In summary, we cannot provide a range of activities for young people and expect qualities related to personal and social education to infuse young people simply through the experience of participation.

Figure 2.2

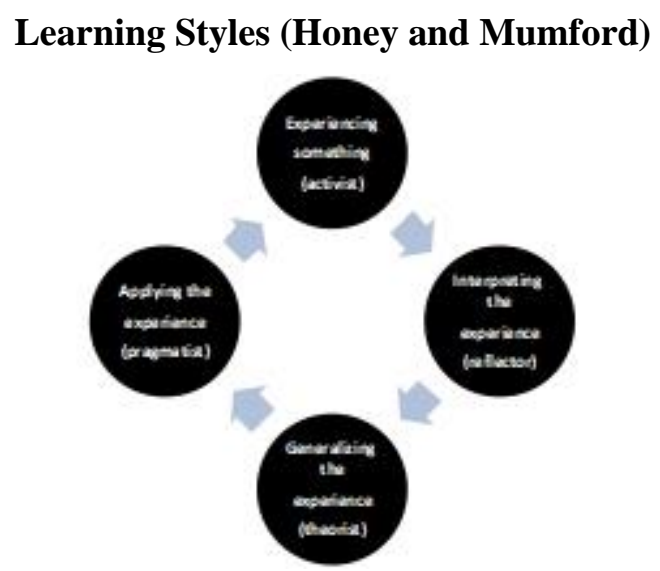

This model can be used to show that people vary in their preferred style of learning (Honey and Mumford, 1992). It implies that people generally show tendencies towards one particular learning style, that of either the activist, reflector, theorist or pragmatist. It is based on Kolb's learning cycle and so the 'activist' is associated with 'experiencing something', the 'reflector' with 'interpreting the experience' and so on.

Consequently the teacher needs to be aware that desired outcomes may depend on different methods for different people. This is where the models can be useful. They help the teacher/instructor to become involved in each young persons' learning cycle allowing them to be alerted at an early stage as to whether their teaching is being effective. This is an extremely important point because it is important to distinguish between teaching strategies (that which the teacher wants the young person to learn) and learning outcomes (that which the young person actually learns). Furthermore it is obvious that each of us (and each student) is capable of learning in a variety of different ways and that to maximise the learning we take from each situation we should try to engage with the experience in all four of these ways (as an activist, reflector, theorist and pragmatist).

Both of these 'models' are based on a circular concept. Whilst this is useful it does not really suggest a progressive dimension to learning. So a number of individuals and agencies have re-interpreted the Kolb Model as a spiral, with the emphasis changing from 'experiencing something' to experimentation in new situations and therefore 'experiencing something new or different'; though clearly this should relate to the particular 'skill' being learnt at that time. It should also be remembered that experiential learning can have a debilitating effect. Just as we can distinguish 
between educative and mis-educative experience it is also possible to say that some experiences inhibit personal growth. One need only reflect on the idea of mis-adventure (Mortlock, 1984) to recognise that when an instructor/teacher fails to select appropriate activities, and the level at which they are to be pursued, then the activity can lower feelings of self-esteem as opposed to raising it. This too is a vital aspect of good practice as an activity which is suitable for some members of the group may turn out to be a negative experience for others. What it boils down to is the need to constantly ask oneself 'why am I doing this activity with these individuals at this time?'

Nasution (2006: 23) states that outdoor activities is not trip, but it only move the class for a while. Outdoor activities is the teaching learning strategies, where the teacher and students come to some relevant certain place to get the number of empirical experience. Therefore, motivation and interest increased. Furthermore, outdoor activities is generally motivated by motivation to look for the certain information, practise the children attitude, develop student interest and appreciation, and enjoy the new experiences.

Roestiyah (2008: 115) states that outdoor activities is not only a pleasant activities, but it is to study or deepen the material with seeing the reality. Outdoor activities is the teaching method that asks students to go to certain place which is out of the classroom to learn or observesomething, such as: exploring the factory, going to the garage, supermarket, traditional market, etc.

According to Mulyasa (2006:189) outdoor activities is one of teaching method that the students are under the teacher guiding and make the certain and concrete aim to go to place or area for learning and observing something. While, Hamalik (2001:29) states that outdoor activities is a visit to certain place outside the class that is done as academic activities and it has an education purpose.

Outdoor activities is very delightful teaching learning method, it because the students will have the pleasant activities and get the enjoyable experience. Teacher and students can go to certain place, such as supermarket, factory, traditional market, etc. Danim (2009:34) states that outdoor activities is the teaching learning strategies, where teacher and students visit the relevant place to get some empirical experiences. Outdoor activities not only bring the students activities out of the class but also they learn something (visit outside the class to do teaching learning activities).

Based on the explanation above, we can conclude that outdoor activities is the teaching learning activities that is done at class outside for learning something, where the students can directly observe an object. The students can also make recreation during the activities and refresh their mind from the boring learning activities.

Outdoor activities can be defined of the round of their school or further place. Not to mention, go to the factory, zoo, museum, hotel, etc. From this activities, students will get the direct experience that can make them interested in the material which is delivered by the teacher, so students want to 
have deepen knowledge by finding information from books or other sources, it can develop their feeling to love their environment too.

In general, outdoor activities is encouraged by motivation to find information about certain thing, exercise students attitude, develop students interest and appreciation, and enjoy the new experiences. That outdoor activities can make the students see directly event and increase the students experience. This experience cannot be got by them in the class only. The life in the 4 walls is very restricted. Meanwhile, they will get so many knowledge that enrich of things which cannot be learnt by them in the class.

\section{Preparation}

In preparation of outdoor activities, teacher needs clearly choose the purpose of learning activities, consider the choosing of technique, call the leader of the object that will be come to consult anything about the activities, the arrangement of mature planning, divide the tasks, prepare the equipments, divide the students into some groups, deliver the one to check the place. Mulyasa (2005:112) says that, at the beginning of outdoor activities, teacher needs to carry out some activities, such as:

a. Choose the sources of community to become the source of teaching learning activities,

b. Analyze the suitability of the learning source with the purpose and school program.

c. Analyze the learning source based on pedagogic values.

d. Relate the learning source with the curriculum, whether is the source of the outdoor activities support and coincide with the demand of the curriculum. If the answer is yes, the outdoor activities can be done.

e. Make and develop the outdoor activities program logically, and systematic.

f. Do the outdoor activities suitability with the purposes that has determined, and observe the learning purposes, learning material, learning effect, and the comfortable weather.

g. Analyze the purpose of outdoor activities whether there are difficulties in the these activities, give the prize to the one who has helped the outdoor activites, make a note from this outdoor activities.

\section{METHOD}

The research method which was used is classroom action research (CAR). CAR is viewed as a device to improve the quality of teaching learning ability in the physical classroom. Beside of solving diagnosed problems in conditional classroom activity, CAR also helps the teacher through any new methods, skills, and strategies through pair-teaching between the researcher and the teacher as collaborative study. It means that this method could help quality of teaching learning 
ability and solve real problems in the classroom through new methods, skills, and strategies through collaborative between researcher and teacher.

Creswell (2008) said that CAR is the practical design which explores a problem with an aim toward developing a solution to a problem, and also action research designs are systematical procedure done by the teachers (or other individual in an educational setting) to improve their teaching, and their students learning. It means that teachers have an aim at improving the practice of education by studying issues or problems they face, and teachers reflect about these problems, collect and analysis data, and also implement changes based on their findings. Meanwhile Wallace (2006) stated that CAR is a type of classroom research that the teacher found the problem in order to solve problems or to find answers toward context-specific issues. It means that to begin the CAR, the researcher or the teacher needs to identify any real problems which are found in the classroom concerning students' condition in teaching-learning process.

In this Classroom Action Research, the writer used Kurt Lewin's design. Kurt Lewin's design for Classroom Action Research consists of four phases within one cycle. Those are planning, acting, observing, and reflecting. Teacher might probably find a new problem or the previous unfinished problem yet after implementing first cycle. If it happens, it is necessary to continue to the second cycle in line with the same concept of the first cycle.

\section{Figure 3.1}

\section{The Processes of CAR}

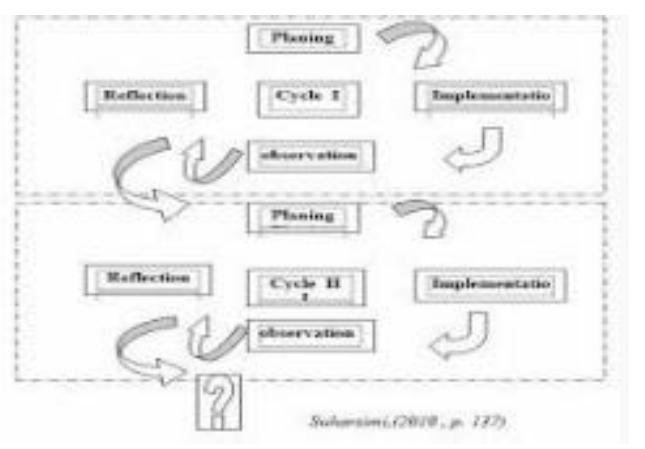

\section{Planning}

The writer planed some actions based on the research goal. The writer prepared learning scenario and the instrument for research, such as teaching aid, observation form and evaluating test.

\section{Acting/Implementing}

The second step of the cycles is acting which is implementation of the planning.

\section{Observing}


The third step is observing students' activities and observing general condition of class in teaching learning process in order to gather relevant data. The writer noted all the things occurring teaching learning process which covers the implementation of the classroom condition, and students' responses during teaching-learning activities.

\section{Reflecting}

In this step, the results of collecting data and analyzing data by the researcher, whether the next cycle need to be continued or not. Meanwhile the research will be stopped if require these criterions.

This research was conducted at SMP Negeri 4 Sipoholon of the eight grade students in academic year 2018/2019. The population of the eight grade is 40 students consisted of two classes $8 \mathrm{~A}$ and $8 \mathrm{~B}$, in which each class consists of 20 students. The subject of this research was one class of the eight grade students of SMP Negeri 4 Sipoholon it was 8A. The subject was taken by applying cluster random sampling. Kumar R. (2011:186) States that "Cluster sampling is based on the ability of the researcher to divide the sampling population into groups (based upon visible or easily identifiable characteristics), called clusters, and then to select elements within each cluster" As a result the total number of the subject of this research is 20 students.

The data used to answer the research problem of this research was quantitative data. There were two tests for each cycle in classroom action research, namely preliminary test (pre-test), and posttest. The pre-test was given before the treatment while the post-test was after the treatment.

Having collected the data, the result of pre-test and post-test was analyzed by using dependent/paired t-test calculation. Peers (1996:121) Argues that when deciding what statistical test to use, three interrelated issues need to be considered:

1. Research question. Is the main research question concerned with association/relationship, dependence/prediction between measures (same individuals), or comparison/differences between groups?

2. Research design. How many groups are there in the study and is there any relationship between them? For example, if there are two or more groups of data are they related or independent? If each set of scores is obtained from a different sample of subjects, the groups are independent. If different measures are obtained from the same group of subjects on two (or more) occasions, i.e. the same subjects take two or more tests, or subjects take the one test on two or more occasions, then the measures are related or dependent.

3. Data distributions. Are the distributions of the important variables discrete with inferences based on count data, for example, binomial, nominal or ranked data? Or are the distributions 
continuous, for example, normal, bivariate normal with inferences based on the normal distribution?

In relation to this statement, the researcher analyzed the data by applying dependent/paired t-test calculation, in addition, to compute the data, the researcher applied excel program proposed by Berk and Carey (2007:244). In relation, for this research is a classroom action research, the level of the students, vocabulary mastery is based on Arikunto (2010:245) as presented in the table below.

The Level of the Students' Vocabulary Mastery

\begin{tabular}{|l|c|c|}
\hline \multicolumn{1}{|c|}{ VALUE } & GRADE & LEVEL OF VOCABULARY MASTERY \\
\hline $80-100$ & A & Very Good \\
\hline $66-79$ & B & Good \\
\hline $56-65$ & C & Fair \\
\hline $40-55$ & D & Poor \\
\hline$<39$ & E & Fail \\
\hline
\end{tabular}

\section{RESULT AND DISCUSSION}

Having administered both pre-test and post-test, the data of the students' score is presented in the table below.

\begin{tabular}{|l|l|c|}
\hline NO & \multicolumn{1}{|c|}{ NAME } & PRE-TEST \\
\hline 1 & ADERISMA HUTAGALUNG & $\mathbf{3 5}$ \\
\hline 2 & ALEX SUDANRO HUTASOIT & $\mathbf{6 0}$ \\
\hline 3 & AMSAL SIMATUPANG & $\mathbf{6 0}$ \\
\hline 4 & ANA TASYA SIMAMORA & $\mathbf{6 0}$ \\
\hline 5 & APRIMA W.S SIPAHUTAR & $\mathbf{6 0}$ \\
\hline 6 & ARTA SIMANUNGKALIT & $\mathbf{4 5}$ \\
\hline 7 & ASTOR DINA LUMBAN GAOL & $\mathbf{6 5}$ \\
\hline 8 & CRISTANTO SIPAHUTAR & $\mathbf{5 0}$ \\
\hline 9 & ENPRINSON M .SIMANUNGKALIT & $\mathbf{6 5}$ \\
\hline 10 & GRETARI HUTASOIT & $\mathbf{5 0}$ \\
\hline 11 & HARDIMAN A.HUTAGALUNG & $\mathbf{6 0}$ \\
\hline 12 & HARI GUNAWAN SIPAHUTAR & $\mathbf{5 0}$ \\
\hline 13 & HOTASI SIPAHUTAR & $\mathbf{6 0}$ \\
\hline 14 & HOTNAGEL HUTAGALUNG & $\mathbf{5 5}$ \\
\hline 15 & INDI PASKA SIPAHUTAR & $\mathbf{6 0}$ \\
\hline 16 & IRELLY SIPAHUTAR & $\mathbf{5 0}$ \\
\hline 17 & ITA P SIPAHUTAR & $\mathbf{6 0}$ \\
\hline 18 & JELITA SIMANUNGKALIT & $\mathbf{6 0}$ \\
\hline 19 & JOSUA P SIPAHUTAR & $\mathbf{5 0}$ \\
\hline 20 & JULVAIF TAMBUNAN & \\
\hline & &
\end{tabular}

112 | Experiential Outdoor Activities In Improving Students' ..., Musrafidin Simanullang Jurnal Christian Humanioran | http://e-journal.iakntarutung.ac.id/index.php/humaniora 
The students' score was analyzed and it was found out that;

\begin{tabular}{|c|c|c|c|}
\hline Interval & Interpret & Freque & Percentag \\
\hline $80-100$ & Very & $\mathbf{0}$ & $0 \%$ \\
\hline $66-79$ & Good & 0 & 0\% \\
\hline $56-65$ & Fair & 11 & $55 \%$ \\
\hline $40-55$ & Poor & 8 & $40 \%$ \\
\hline$<39$ & Fail & 1 & $5 \%$ \\
\hline \multicolumn{2}{|c|}{2} & 20 & $100 \%$ \\
\hline
\end{tabular}

Based on the table above it can be concluded that there was not student who got good and very good interpretation yet there are one who was fail and 8 students who were poor, in the minimum criterion used in the school is 70 , so the researcher concluded that based on the students' pre-test score they are fail.

The post-test was administered after taught or given the students treatment, that was experiential out-door activities, the students' score is presented in the table below.

\begin{tabular}{|l|l|c|}
\hline NO & \multicolumn{1}{|c|}{ NAME } & POST-TEST \\
\hline 1 & ADERISMA HUTAGALUNG & $\mathbf{7 5}$ \\
\hline 2 & ALEX SUDANRO HUTASOIT & $\mathbf{8 0}$ \\
\hline 3 & AMSAL SIMATUPANG & $\mathbf{7 5}$ \\
\hline 4 & ANA TASYA SIMAMORA & $\mathbf{7 5}$ \\
\hline 5 & APRIMA W.S SIPAHUTAR & $\mathbf{7 5}$ \\
\hline 6 & ARTA SIMANUNGKALIT & $\mathbf{8 0}$ \\
\hline 7 & ASTOR DINA LUMBAN GAOL & $\mathbf{7 5}$ \\
\hline 8 & CRISTANTO SIPAHUTAR & $\mathbf{8 0}$ \\
\hline 9 & ENPRINSON M .SIMANUNGKALIT & $\mathbf{8 5}$ \\
\hline 10 & GRETARI HUTASOIT & $\mathbf{7 5}$ \\
\hline 11 & HARDIMAN A.HUTAGALUNG & $\mathbf{8 0}$ \\
\hline 12 & HARI GUNAWAN SIPAHUTAR & $\mathbf{7 5}$ \\
\hline 13 & HOTASI SIPAHUTAR & $\mathbf{8 0}$ \\
\hline 14 & HOTNAGEL HUTAGALUNG & $\mathbf{8 0}$ \\
\hline 15 & INDI PASKA SIPAHUTAR & $\mathbf{7 5}$ \\
\hline 16 & IRELLY SIPAHUTAR & $\mathbf{8 0}$ \\
\hline 17 & ITA P SIPAHUTAR & $\mathbf{7 5}$ \\
\hline 18 & JELITA SIMANUNGKALIT & $\mathbf{8 0}$ \\
\hline 19 & JOSUA P SIPAHUTAR & \\
\hline 20 & JULVAIF TAMBUNAN & \\
\hline & & \\
\hline
\end{tabular}


The Students' Degree Mastery Score of Post-test

\begin{tabular}{|l|l|c|c|}
\hline Interval & Interpretation & Frequency & Percentage \\
\hline $80-100$ & Very Good & $\mathbf{1 1}$ & $\mathbf{5 5 \%}$ \\
\hline $66-79$ & Good & $\mathbf{9}$ & $\mathbf{4 5 \%}$ \\
\hline $56-65$ & Fair & $\mathbf{0}$ & $\mathbf{0 \%}$ \\
\hline $40-55$ & Poor & $\mathbf{0}$ & $\mathbf{0 \%}$ \\
\hline$<39$ & Fail & $\mathbf{0}$ & $\mathbf{0 \%}$ \\
\hline \multicolumn{2}{|c|}{$\sum$} & $\mathbf{2 0}$ & $\mathbf{1 0 0 \%}$ \\
\hline
\end{tabular}

Based on the table above it can be concluded that there are 11 students who got very good ( 80 $100)$ and 9 students got good (66 - 79), and none of the students got fair (56-65), poor (40-55), and fail $(<39)$. It means all the students passed the minimum criterion applied in that school. On the other hand, it can be concluded that experiential out-activities significantly improves the students' vocabulary mastery/achievement. In analyzing the data, the researcher computed it by applying Excel Data Analysis Program, and the result is presented in the table below.

\section{The Result of Paired/Dependent t-test analysis}

t-Test: Paired Two Sample for Means

\begin{tabular}{lrr}
\hline & Post Test & Pre-Test \\
\hline Mean & 78.25 & 55.25 \\
Variance & 11.25 & 56.51316 \\
Observations & 20 & 20 \\
Pearson & 0.540102 & \\
Hypothesized & 0 & \\
Df & 19 & \\
t Stat & 16.1575 & \\
P(T<=t) one- & $7.39 \mathrm{E}-13$ & \\
t Critical & 1.729133 & \\
P(T<=t) two- & $1.48 \mathrm{E}-12$ & \\
t Critical & 2.093024 & \\
\hline
\end{tabular}

Based on the above, it can be concluded that the mean of students' post test score is higher than the mean of students' pre-test score or $78.25>55.25$. In addition, by comparing the tvalue with the p-value under df (degree of freedom) is 19 or 1.729 , it was found t-value has a significant different with t-table or $78.25>1.729$. On the other hand, it can be said that the Ho (null hypothesis) is rejected and the Ha (alternative hypothesis) is accepted, in which there is 
a significant improvement of students' vocabulary achievement/mastery taught by experiential outdoor activities.

\section{CONCLUSION}

Based on the data analysis that there are 11 students who got very good $(80-100)$ and 9 students got good (66 - 79), and none of the students got fair (56-65), poor (40-55), and fail $(<39)$. It means all the students passed the minimum criterion applied in that school. On the other hand, it can be concluded that experiential out-activities significantly improves the students' vocabulary mastery.

Besides, by analyzing the data through t-test, it can be concluded that the mean of students' post test score is higher than the mean of students' pre-test score or $78.25>55.25$. In addition, by comparing the t-value with the p-value under $\mathrm{df}$ (degree of freedom) is 19 or 1.729 , it was found that t-value has a significant different with t-table or $78.25>1.729$. On the other hand, it can be said that the Ho (null hypothesis) is rejected and the Ha (alternative hypothesis) is accepted, in which there is a significant improvement of students' vocabulary achievement/mastery taught by experiential outdoor activities.

\subsection{Suggestion}

As the result of the research gives a significant improvement, the researcher would like to suggest.

a) For teacher

- The teacher should try Outdoor Activities that can be used as an alternative to teach English especially vocabulary to the students.

- The teacher should also create more relaxed atmospheres in teaching learning process by giving chance to the students to use the target language.

- The teacher should be as creative as possible in teaching vocabulary through Outdoor Activities.

b) For students

- The students should study hard to get good vocabulary mastery;

- The students should be motivated and think that vocabulary is interesting by discussion with partner in Outdoor Activities in teaching learning process.

- The student should also have high motivation to learn vocabulary English texts and practice what they have learned from their teacher everywhere and every time.

c) For other researchers 
Beside this research is beneficial as a reference for research specified on English vocabulary, other researchers are expected to do a similar research with a similar topic by using a wider scope and larger population. Therefore, the result will be more applicable in a tertiary level.

\section{ACKNOWLEDGEMENT}

I would like to thank the following people for helping with this research project; The English students of The University of Sisingamangaraja XII Tapanuli (UNITA) in Academic Year 2018 2019, The Dean of FKIP, Dr. Meslin Silalahi, M.Pd, and all the English Lecturers at The University of Sisingamangaraja XII Tapanuli (UNITA) for their willingness to impart their knowledge and guidance.

\section{REFERENCES}

Burn, Anne. 1999. Collaborative Action Research for English Language Teachers. Cambridge: Cambridge University Press.

Creswell, John w., Educational Research. Pearson Educational International, 2008.

Dewey, J. (1963) Experience and Education. London: Collier-Macmillan.

Danim, Sudarwan. 2009. Metode Belajar Mengajar. Jakarta: Angkasa

Honey, P. and Mumford, A. (1992) Manual of Learning Styles. Maidenhead: Honey Publications.

Hatch, Evelyn, and Cheryl Brown. 1995. Vocabulary, Semantic and Language Education. Cambridge: Cambridge University Press.

Hamalik, D. 2005. Media Pendidikan. Bandung: Alumni.

Hornby. 1995. Advance Learner"s Dictionary. Newyork: Oxford University Press.

Mulyasa. 2005. Didaktik dan Metodik Umum, Jakarta: PT Rineka Cipta.

Nasution, S. 2006. Didaktik Asas-asas Mengajar. Bandung: Jemmars.

Roestiyah. 2008. Strategi Belajar Mengajar, Jakarta: PT Rineka Cipta.

Tarigan,. 1988. PengajaranPemerolehan Bahasa. Bandung: Angkasa.

Ur, Penny. 1996. A Course In Language Teaching. Melbourne: Cambridge University Pers

116 | Experiential Outdoor Activities In Improving Students' ..., Musrafidin Simanullang Jurnal Christian Humanioran | http://e-journal.iakntarutung.ac.id/index.php/humaniora 